\title{
Application of Geographic Information System (GIS) For Urban Renewal: A Case Study of Yelwan Tudu of Bauchi State, Nigeria
}

\author{
Efunnuga Oluwayemisi Bunmi1 ${ }^{1}$, Ituma Chijioke Gideon², Idakwo Victor Iko-0jo ${ }^{1}$ \\ 1Department of Urban and Regional Planning, Faculty of Environmental Technology, \\ ${ }^{1}$ Abubaka Tafawa Belewa University Bauchi, Nigeria \\ 2Department of Industrial Physics, Ebonyi State University, Abakaliki, Nigeria
}

\begin{abstract}
Urban renewal has been regarded as a sound approach to promoting land values and improving environmental quality. An urban renewal programs is supposed to address undesirable urban conditions. However, the real problem in this regard is that the determination of the level of substandard situations that can be considered undesirable is usually based on planning standards and varies from place to place and time to time. This study attempts to review the general concept of urban renewal and various approaches. It highlights the existing physical and socio-economic characteristics of the study area. To establish how urban renewal programs can be achieved simultaneously using GIS .The methodology included digital mapping techniques, ground survey to establish the factors responsible for deterioration in the study area, conversion of surveyed data into digital form as attribute of the spatial data (variables considered) and query of each variables to show individual conditions in the study area. The results obtained showed that GIS easily allowed the linking of spatial data with attribute data based on which queries and spatial analysis carried out. The level of deterioration is determined using weighted index analysis method of identifying a slum, thus major rehabilitation is suggested as the best approach for the study area. Finally, a renewal plan is proposed as way of solving the identified problems in the study area.
\end{abstract}

\section{KEYWORDS: Urban Renewal, GIS, Deterioration}

\section{INTRODUCTION}

Urban renewal is a common phrase among planners, land use experts and politicians whose dreams and aspiration are usually targeted at seeing that the area of their interest is put to its highest and best use in strict conformity with the conceived planning design [1]. Preliminary observation of Yelwan Tudu revealed rapid growth development; new structures are being erected with no regards to planning standards, undesirable living conditions. These issues has led to the formation of slum condition in the area, therefore the process of renewal is needed so as to achieve a very conducive living environment. Urban renewal implies a process where an urban neighborhood or area is improved and rehabilitated. The renewal process can include demolishing old or run-down buildings, constructing new, up-to-date housing, or adding in features like a theater or stadium. Urban renewal is usually undergone for the purposes of persuading wealthier individuals to come live in that area. Urban renewal is often part of gentrification process (BusinessDictionary.com).

Yelwan Tudu area is presently facing problems of poor sanitary conditions caused by indiscriminate litter of refuse and sewage, dilapidated structures, high occupancy ratio, high rate of crime, physical dullness in terms of landscaping and other social amenities, bad drainagesystem or lack of drainage in some streets, and poor maintenance of the existing few.

Previous studies has revealed that the factors responsible for deterioration in the study area can be traced to rapid urbanization, rural-urban migration, steady economic system, decay of urban infrastructure, poor quality of original construction, lack of integrated planning, negligent urban housekeeping, inadequate methods of preservation of infrastructure, the presence of public services [2]. The hideous situation of Yelwan Tudu exposes the residents to pollution, health problems, robbery, and individual behavioral pattern of children brought up in this area unlike to those nurtured in decent environments. It has become very important not only to address the situation but also provide a lasting solution to the problems identified.

\section{Aim of the Study}

The aim of this study is to assess the physical and socioeconomic characteristics of Yelwan Tudu area with a view to propose a renewal plan for the overall wellbeing of the area.

\section{Location of the Study Area}

This study was carried out in some selected communities in Yelwan tudu, a local government in Bauchi State, Nigeria as shown in Fig. 1 and Fig. 2.

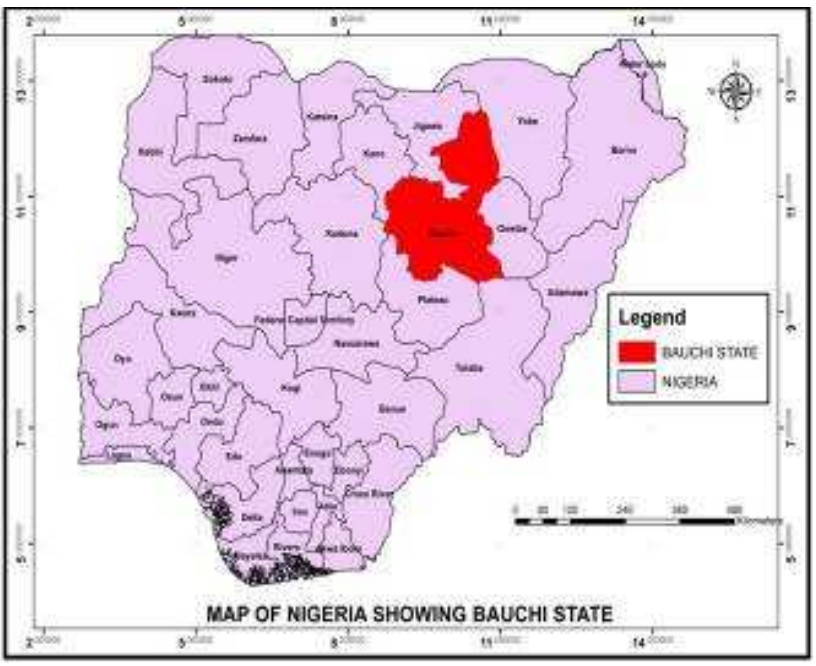

Figure 1: Map of Nigeria showing Bauchi State 


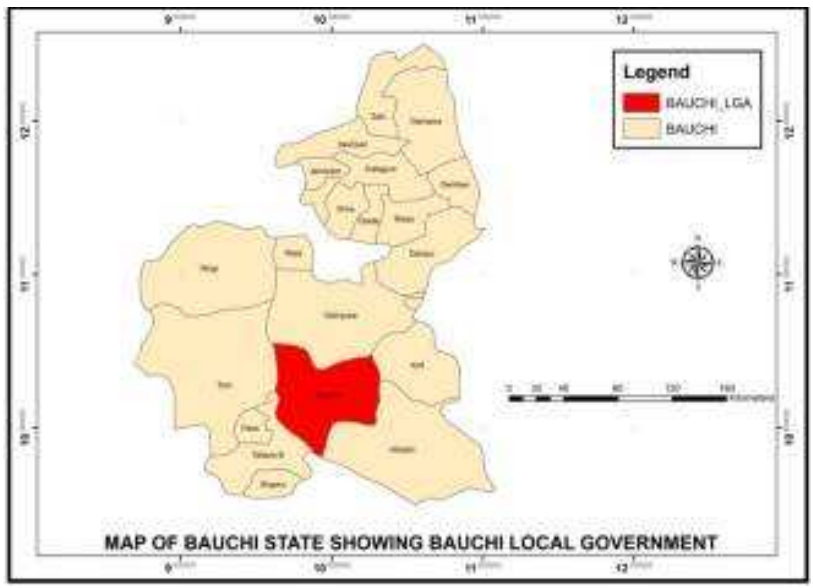

Figure 2: Map of Bauchi showing Bauchi Local Government Area.

\section{MATERIALS AND METHOD}

Bauchi metropolis is located within coordinates located between latitudes $9^{\circ} 3^{\prime}$ and $12^{\circ} 3^{\prime}$ north and longitudes $8^{\circ}$ $50^{\prime}$ and 110 east. Yelwan Tudu is located in Bauchi local government area which falls within Bauchi metropolis. Yelwan Tudu is bounded by Unity College to the north, Yelwan kagadama to the south, Lushi village to the east and Angwan cashew to the west.

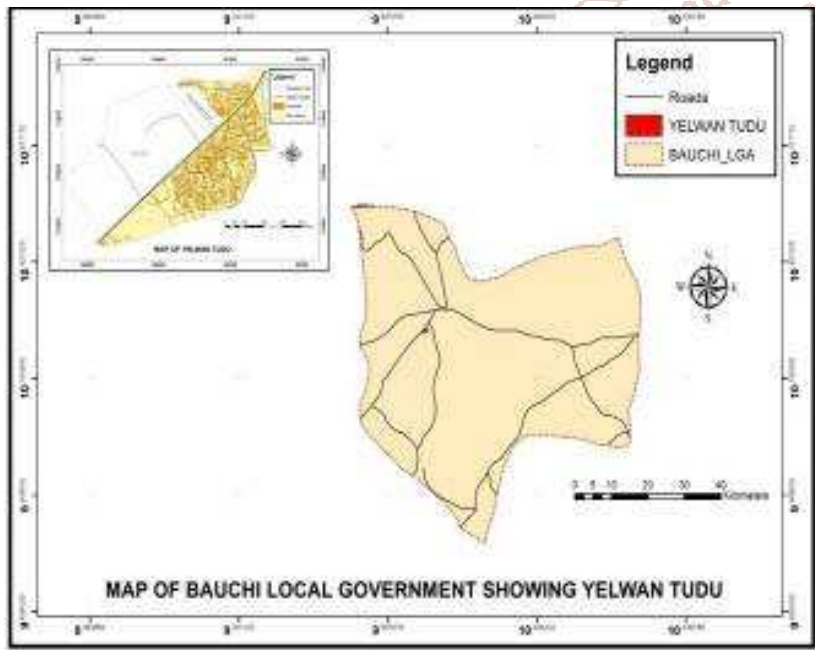

Figure 3: Map of Bauchi Local Government Area showing the study area

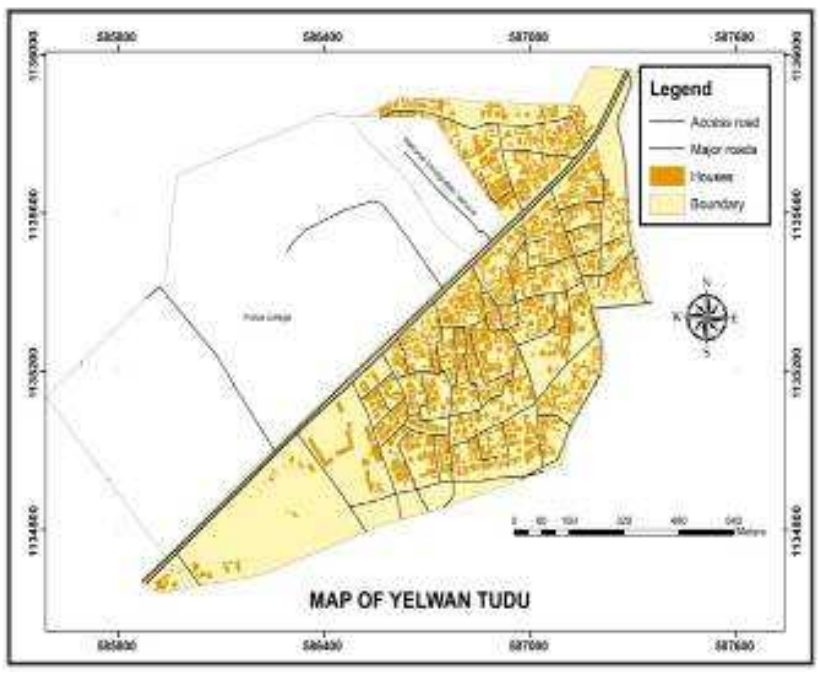

Figure 4: Map of Yelwan Tudu

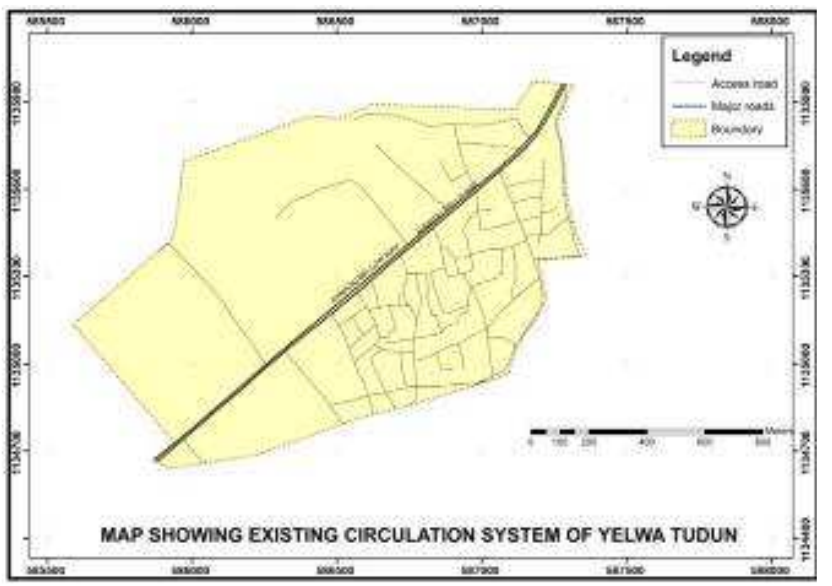

Figure 5: Map showing the existing circulation system of Yelwan Tudu

\section{METHODOLOGY STRUCTURE}

The methodology adopted has three stages of map preparation, attribute data generation, GIS data input and analysis.

\section{A. Stage 1: Preparation of Base Map}

To prepare the base map Yelwan Tudu, GIS techniques was employed. To obtain reasonable precision in the mapping process, a $10 \mathrm{~m}$ resolution imagery of Yelwan Tudu was obtained and coordinate points were there after taken for the purpose of geo-referencing. The imagery (Google Earth Pro 2012) was imported as a JPEG file into the ArcGis 10.1software environment and geo-referenced using the already obtained coordinate points.

\section{B. Stage 2: Generation of attribute data and database} creation

The generation of attribute data involved field survey of the study area in which basic data sets were collected. This includes, the spatial information defining each individual property and its boundary; and the attribute data associated with each property. This information was gathered verbally via individual household data form, which was transformed as attributes into map form with the use of ArcGis. In developing various maps, showing the variables for determining the level of deterioration and using the number of buildings in the study area as guiding criteria is essential. The surveyed plan was later used as a way of referencing or linking the attribute data with the corresponding spatial data to create a database.

\section{Stage 3: GIS data input and analysis}

To gain insight into the overall physical and sociocharacteristics of the study area, the database needs to be queried to reveal the current condition of each variable based on the criteria for determining each variable. This was achieved using the select by attribute query module in ArcGIS 10.1 The overall aim here was to classify the condition of each variable as bad, fair or good. This categorization is based weighted index analysis.

\section{PHYSICAL CHARACTERSITICS}

\section{A. Climate Condition}

Yelwan Tudu has a rainfall regime ranging from 1,300mm per annum in the south which starts in the month of April. In contrast, the north receives rain late around the month of June/July with a maximum of $700 \mathrm{~mm}$ per annum. 


\section{B. Humidity}

The humidity in the area is humidly hot during the early part of the rainy season. While towards the EMBER months and early January, there is cold weather. The relative humidity shows a marked decrease from the early morning to the afternoon throughout the year. Associated with the high relative humidity the cloudiness over the area is usually extensive.

\section{Wind}

The wind direction is mostly dominated by the seasonal movement of inter-tropical convergence zone which represents the moving frontier between most Atlantic air from the south and the dry air from the Sahara.

\section{Vegetation}

The area covers the Sudan Savannah where the vegetation gets richer towards the south especially along water source or rivers but generally, the vegetation is less uniform and grasses are shorter than what obtains further south that is the forest zones of the middle belt.

\section{E. Topography}

It entails the sloppiness or gradient of an area. The topography of Yelwan Tudu is relatively flat.

\section{F. Temperature}

Highest temperature always tends to occur at the end of the dry season close to spring equinox. Thus March has the highest temperature. The lowest temperature occurs in the middle of the dry season in December or January.

\section{SOURCES OF DATA COLLECTION}

Basically, there are two major sources of data; primary and secondary source.

$>$ Primary data; Primary data used in the research include data obtained using the individual household interview data form and satellite images of the study area. The individual household interview data form focused on the five indicators: sources of water supply, means of waste disposal, income level, age of building and building condition. Qualitative data, in the form of recent satellite imageries was also used. In addition, relevant information was extracted from existing and related studies on the subject matter and study area. The selected neighborhood serves as sample frame boundary for the research, in which the individual house units are the sample units

$>$ Secondary source; data is collected through the following; Internet, Journals, Books, Dissertations, and Encyclopedia etc.

\section{FACTORS RESPONSIBLE FOR THE DETERIORATION OF YELWAN TUDU}

There are basically five types of techniques, which are commonly used to determine the extend or factors responsible for the deterioration in any urban area. The essence of these techniques is to devise strategies responsible for the physical condition of housing, facilities, utilities, services and the general environmental quality of any urban area, so as to determine the appropriate renewal plan to be implemented in order to improve the general living standard of people.

$>$ Cost Benefit Analysis

$>$ Multi-variant Analysis

$>$ Rough Screening Method

$>$ Weighted Index Analysis

$>$ Multiple Index Analysis

\section{A. Weighted Index Analysis}

This is a multi-criteria urban renewal technique .At this stage the variables and criteria are weighted based on their level of importance to produce the levels of deterioration for each variable in the study area. In this method, the assessment is more detailed but proceeds like the rough screening method in the following steps;

$>$ As in rough screening method

$>$ Assess the area on all the criteria of buildings and environmental conditions using quantifiable scores values. This involves deciding weights for the criteria based on residents, priorities and other critical conditions

Rank the zones into grades needing specific renewal actions. This involves the total weighted scores for the zones and then grading the zones based on a chosen sliding scale.

This method as applied to the study area was partly based on the field survey, observation made and partly individual resident preference to utilities, facilities and services and their general conceptions about them.

Weight each blight or slum indicator from 3 to 1 scores as the indicators in the respective variable or unit. The lower the score, the higher the slum intensity as indicated below:

Key:

3-Good

2-Fair

1-Bad

The total weight scores from each zone are put into scale 1-3 to determine the level of deterioration and the planning action to be required.

\section{B. Composite Level of Deterioration}

This is the general map overlay of the variables to produce the final deterioration levels by score

Table1. Weight Score and Action Required

\begin{tabular}{|c|c|c|}
\hline $\begin{array}{c}\text { Level of } \\
\text { Deterioration }\end{array}$ & $\begin{array}{c}\text { Category of } \\
\text { Deterioration }\end{array}$ & $\begin{array}{c}\text { Planning Action } \\
\text { Required }\end{array}$ \\
\hline $1^{\text {st }}$ Order & Bad & $\begin{array}{c}\text { Total Clearance/ } \\
\text { Redevelopment }\end{array}$ \\
\hline $2^{\text {nd }}$ Order & Fair & Upgrade \\
\hline $3^{\text {rd } O r d e r ~}$ & Good & Rehabilitation \\
\hline \multicolumn{3}{|c}{ Source [3] }
\end{tabular}


International Journal of Trend in Scientific Research and Development (IJTSRD) @ www.ijtsrd.com eISSN: 2456-6470

Table2. Variables for evaluating physical condition of the study area

\begin{tabular}{|c|c|c|c|}
\hline Major Variables & Sub-Variables & Criteria & scores \\
\hline Land use & Land use types & $\begin{array}{l}\text { Comparism between existing land uses and } \\
\text { land use standard }\end{array}$ & \\
\hline \multirow{13}{*}{ Utilities, Facilities and Services } & \multirow{3}{*}{ Schools } & $0400 \mathrm{~m}$ & \\
\hline & & $400 \mathrm{~m} 800 \mathrm{~m}$ & \\
\hline & & $800 \mathrm{~m}$ - above & \\
\hline & \multirow{3}{*}{ Health Facilities } & $0400 \mathrm{~m}$ & \\
\hline & & $400 \mathrm{~m} 800 \mathrm{~m}$ & \\
\hline & & $800 \mathrm{~m}$ - above & \\
\hline & \multirow{3}{*}{ Means of waste disposal } & Dump site & \\
\hline & & Burning of waste & \\
\hline & & Dust bin & \\
\hline & \multirow{4}{*}{ Sources of water supply } & None & \\
\hline & & Well & \\
\hline & & Borehole & \\
\hline & & Tap & \\
\hline \multirow{6}{*}{ Building } & \multirow{3}{*}{ Building Age } & Less than 20 years & 3 good \\
\hline & & 2040 years & 2 fair \\
\hline & & 40 above & 1 - bad \\
\hline & \multirow{3}{*}{ Building Condition } & Periodic maintenance & 3 good \\
\hline & & Low level of maintenance & 2 fair \\
\hline & & No maintenance & $1-$ bad \\
\hline \multirow{3}{*}{ Income Level } & & Below 15,000 & 1 low \\
\hline & & $15,00025,000$ & 2 medium \\
\hline & & 25000 - above & 3 - high \\
\hline
\end{tabular}

\section{RESULT AND DISCUSSION}

The importance of urban renewal is to improve the environmental quality and living standard of people so as to achieve functional and aesthetic environment. Data presentation and analysis is the process of organizing, grouping and analyzing the existing physical and socio-economic data, using the urban renewal techniques to determine the level of deterioration.

The total land area coverage of Yelwan Tudu is 147.37 hectares, having a total population of 9595.Below is the tabular representation of population distribution of the study area.

Table3. Age Sex Distribution

\begin{tabular}{|c|c|c|c|c|c|c|}
\hline Age & Male & Percentage & Female & Percentage & Total & Percentage \\
\hline 04 & 936 & 9.75 & 867 & 9.04 & 1803 & 18.79 \\
\hline 59 & 548 & 5.71 & 479 & 4.99 & 1027 & 10.70 \\
\hline $10-14$ & 324 & 3.37 & 255 & 2.65 & 579 & 6.02 \\
\hline $15-19$ & 354 & 3.68 & 385 & 4.01 & 609 & 7.69 \\
\hline 2024 & 491 & 5.11 & 462 & 4.81 & 953 & 9.92 \\
\hline 2529 & 562 & 5.85 & 593 & 6.18 & 1155 & 12.03 \\
\hline 3034 & 398 & 4.14 & 429 & 4.47 & 827 & 8.61 \\
\hline 3539 & 235 & 2.44 & 266 & 2.77 & 501 & 5.21 \\
\hline 4044 & 302 & 3.14 & 331 & 3.44 & 633 & 6.58 \\
\hline 4549 & 205 & 2.13 & 236 & 2.46 & 441 & 4.59 \\
\hline 5054 & 165 & 1.71 & 196 & 2.04 & 361 & 3.75 \\
\hline 5559 & 198 & 2.10 & 159 & 1.65 & 357 & 3.75 \\
\hline 60 - above & 114 & 1.23 & 105 & 1.10 & 219 & 2.33 \\
\hline Total & $\mathbf{4 8 3 2}$ & $\mathbf{5 0 . 3 6}$ & $\mathbf{4 7 6 3}$ & $\mathbf{4 9 . 6 4}$ & $\mathbf{9 5 9 5}$ & $\mathbf{1 0 0 . 0}$ \\
\hline
\end{tabular}

Source, field survey, 2017

\section{LAND USE ANALYSIS}

Table 4: Existing Land Use Budget of the Study Area

\begin{tabular}{|c|c|c|c|}
\hline Land Uses & Meter $(\mathbf{m} 2)$ & Hectares & Percentage(\%) \\
\hline Commercial & 18212 & 1.82 & 1.24 \\
\hline Recreation & 1606 & 0.16 & 0.11 \\
\hline Residential & 342070 & 34.21 & 23.21 \\
\hline Public/Semi Public & 764935 & 76.48 & 51.90 \\
\hline Circulation & 223094 & 22.31 & 15.14 \\
\hline Open spaces & 123853 & 12.39 & 8.40 \\
\hline Total & 1473770 & 147.37 & 100 \\
\hline
\end{tabular}

Source, field survey, 2017 
International Journal of Trend in Scientific Research and Development (IJTSRD) @ www.ijtsrd.com eISSN: 2456-6470

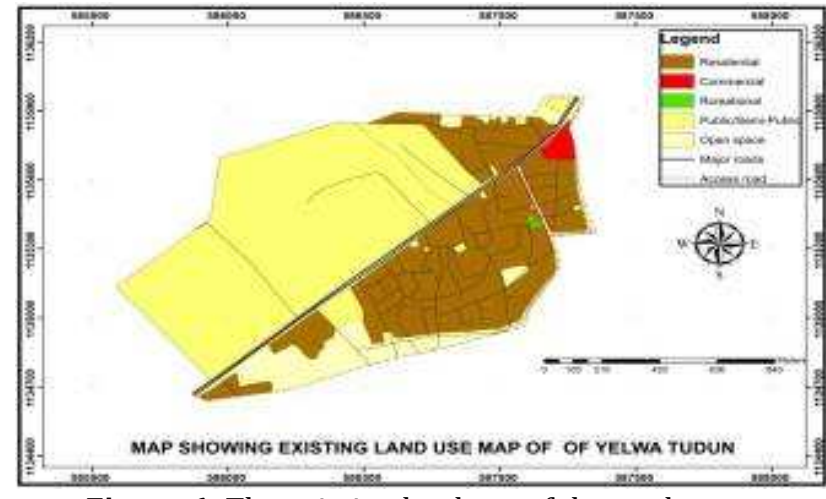

Figure 6: The existing land use of the study area

From Fig. 6, the study shows that public/semi-public land use has the highest percentage due to the presence of the police barrack and national immigration service in the study area. The commercial and recreational land uses has the smallest percentage. Therefore, there is need to pave ways for more commercial and recreational land use to serve the residents of the study area more efficiently.

\section{DISTANCE TO SCHOOL}

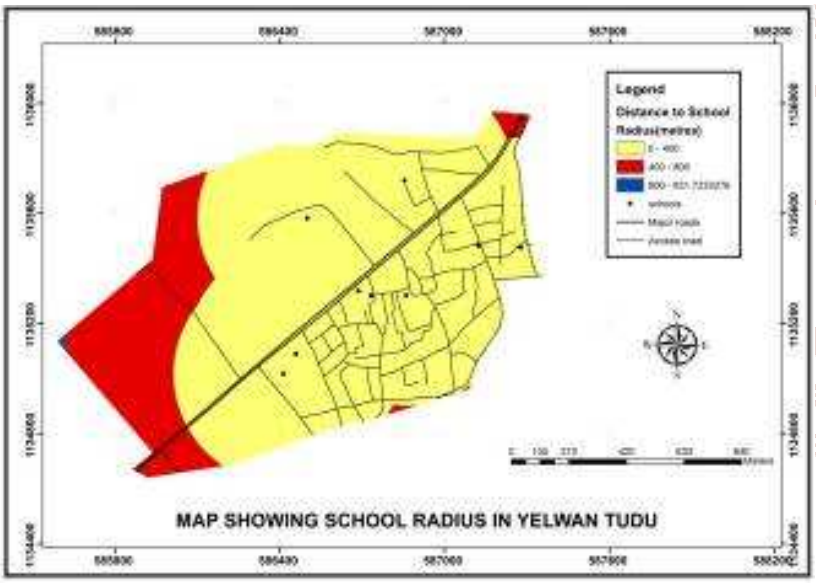

Figure 7: The distance to school in the study area

From Fig. 7, it shows that the distance from schools to individual household are adequately distributed according to planning standard for a residential neighborhood plan [4].

\section{DISTANCE TO HEALTH FACILITIES}

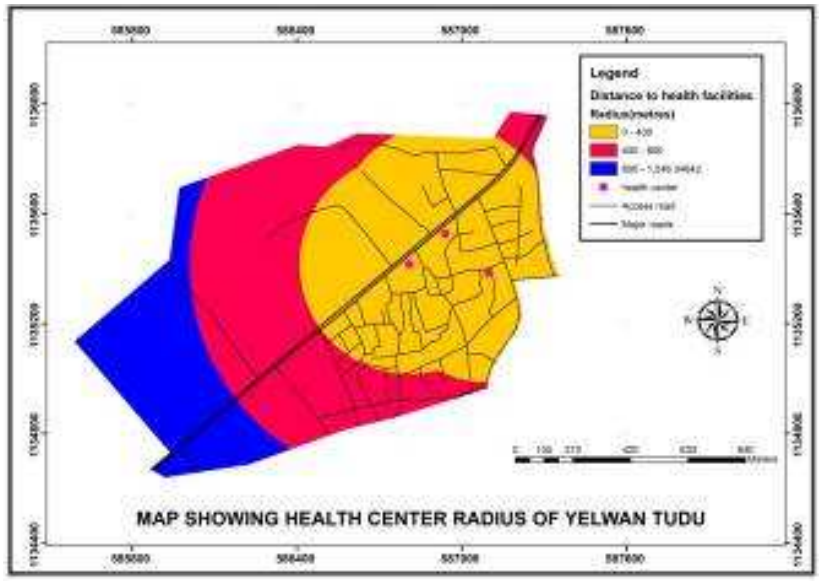

Figure 8: The distance to health facilities in the study area.

Fig. 8 shows that the distance from health facilities to individual household are adequately distributed according to planning standard for a residential neighborhood plan [5].

\section{MEANS OF WASTE DISPOSAL}

Table5. Means of Waste Disposal in the Study Area

\begin{tabular}{|c|c|c|}
\hline $\begin{array}{c}\text { Means of waste } \\
\text { disposal }\end{array}$ & Population & Percentage \\
\hline Dump - site & 6329 & 65.96 \\
\hline Burning of waste & 2424 & 25.26 \\
\hline Dust bin & 842 & 8.78 \\
\hline Total & 9595 & 100 \\
\hline
\end{tabular}

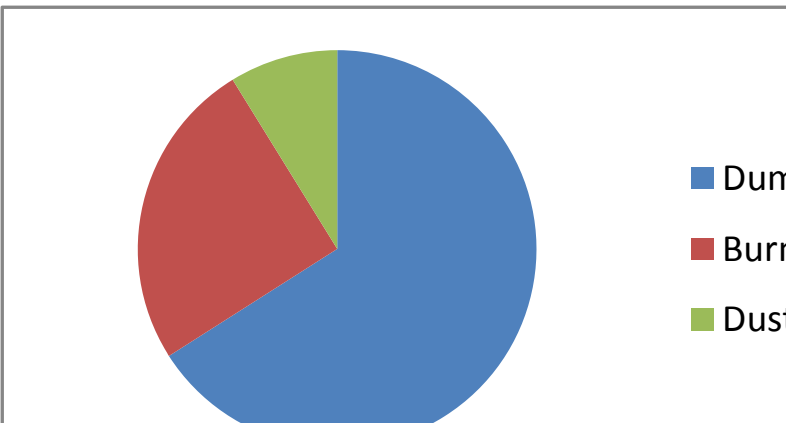

Figure 9: A pie chart showing means of waste disposal

From the survey carried out, Fig. 9 shows that $65.96 \%$ dump their waste, $25.26 \%$ burn their waste and $8.76 \%$ uses dustbin. This shows the poor management of refuse which will lead to unhealthy environment both in terms of aesthetics and air quality.

\section{SOURCES OF WATER SUPPLY IN THE STUDY AREA}

\begin{tabular}{|cc|c|c|}
\hline \multicolumn{2}{|c|}{ Source of water supply } & Population & Percentage \\
\hline and & None & 200 & 2.08 \\
\hline Went & Well & 1125 & 11.72 \\
\hline Borehole & 3950 & 41.16 \\
\hline Tap & 4520 & 47.10 \\
\hline Total & $\mathbf{9 5 9 5}$ & $\mathbf{1 0 0}$ \\
\hline
\end{tabular}

Source, field survey, 2017

\section{BUILDING AGE}

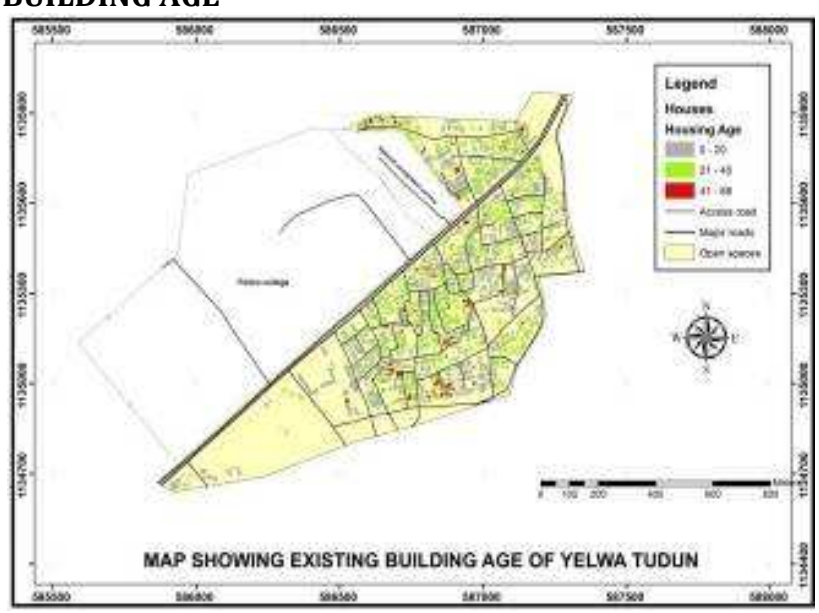

Figure 10: Map showing the Building Age of the study area

Fig. 10 above map shows the weighted score of the building age in the study area. Buildings ranging from 0-20 years, 2140 years, and 41-68 years this may help in the condition of the houses in the area. 


\section{BUILDING CONDITION}

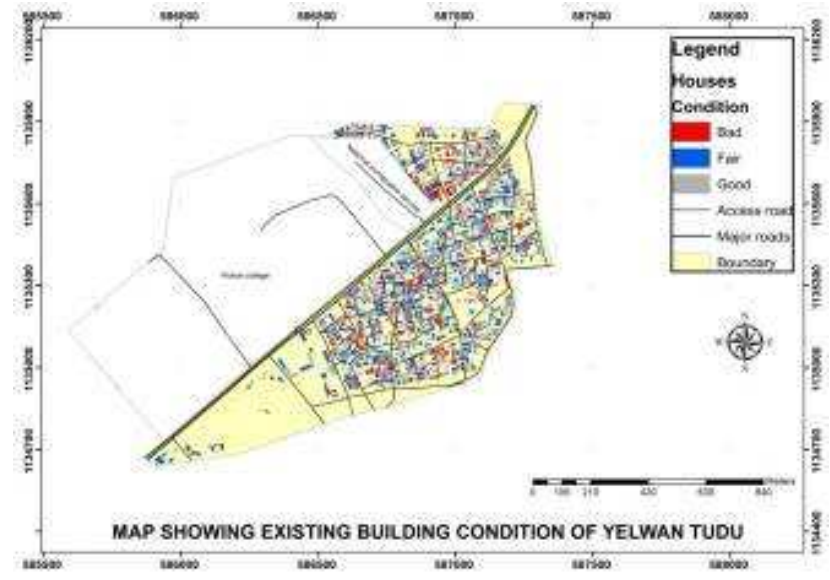

Figure 11: Map showing the building condition of the study area.

Based on Fig. 11, the weighted score of the building condition in the study area is 3 good (periodic maintenance), 2 fair (low level of maintenance), 1 bad (no maintenance).

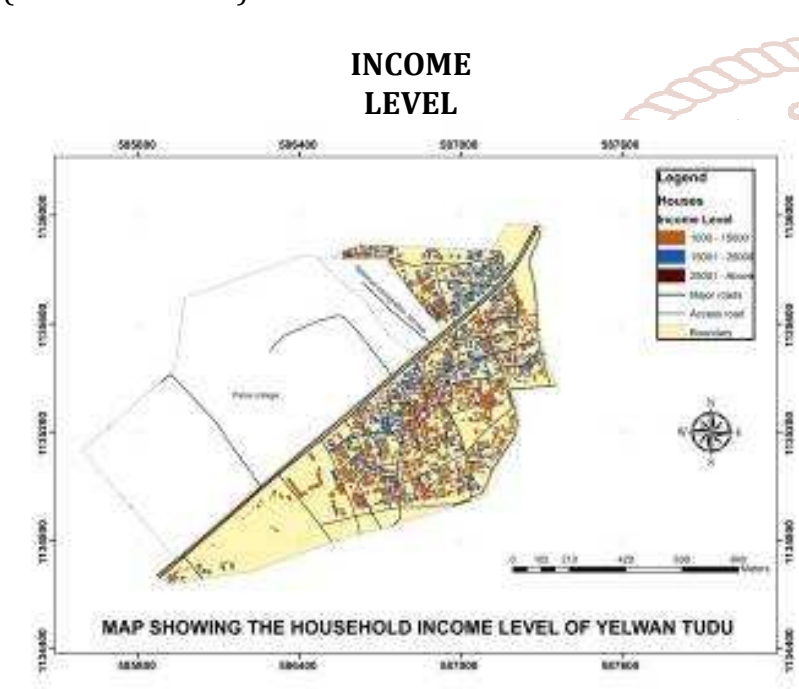

Figure 12: The income level of the study area.

Fig. 12 map shows the income level of the study area. The study area is mostly dominated by average income earners.

\section{SUMMARY OF FINDINGS}

To achieve the goal of renewal, various variables were adopted and the following forms the summary of findings.

\section{A. Population}

The survey shows that the study area has a total population of 9595 with a total land area of 147.7 hectares of land, with 4832 as males accounting for $50.36 \%$, female accounts for 4763 representing $49.64 \%$.

\section{B. Existing Land Use}

The survey shows that public/semi-public lands use dominate other land uses due to the presence of the police barrack and national immigration service. Commercial and recreational land uses has the smallest percentage in the study area. Therefore, there is need to pave ways for these land uses in the study area.

\section{Road and Circulation}

$80 \%$ of the Access road is untarred.

\section{Distance to school}

The criteria used in this study to determine individual household to school includes the following; 0-400m ,400$800 \mathrm{~m}, 800$ - above(standard to determine school distance radius in a residential neighborhood plan) [4].Therefore, the school are adequately distributed.

\section{E. Distance to Health facilities}

The criteria used in this study to determine individual household to health facilities includes the following; $0-400 \mathrm{~m}$ ,400-800m ,800- above(standard to determine health facilities distance radius in a residential neighborhood plan)[4].Therefore, the health facilities are adequately distributed.

\section{F. Means of waste disposal}

$65.96 \%$ of the total population disposes waste by means of dump-site. $25.26 \%$ of the total population disposes waste by means of burning of waste.8.78\% of the total population disposes waste by means of dust-bin.

\section{PLAN PROPOSAL}

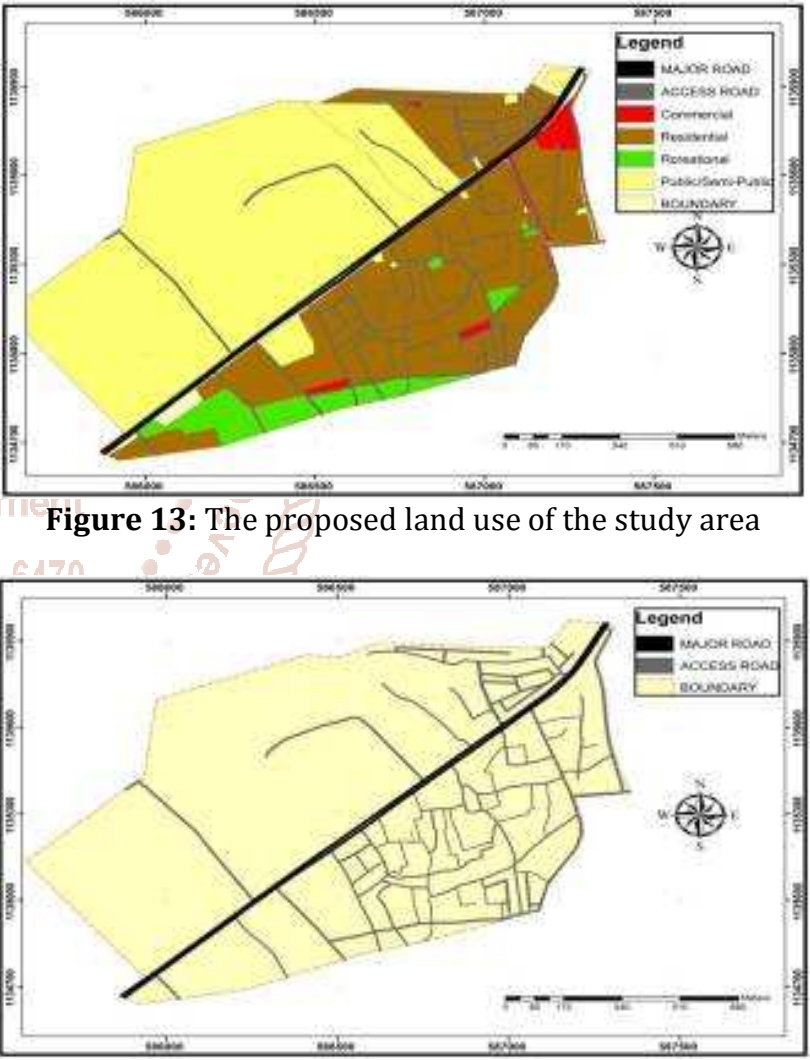

Figure 14: The proposed road network for the study area

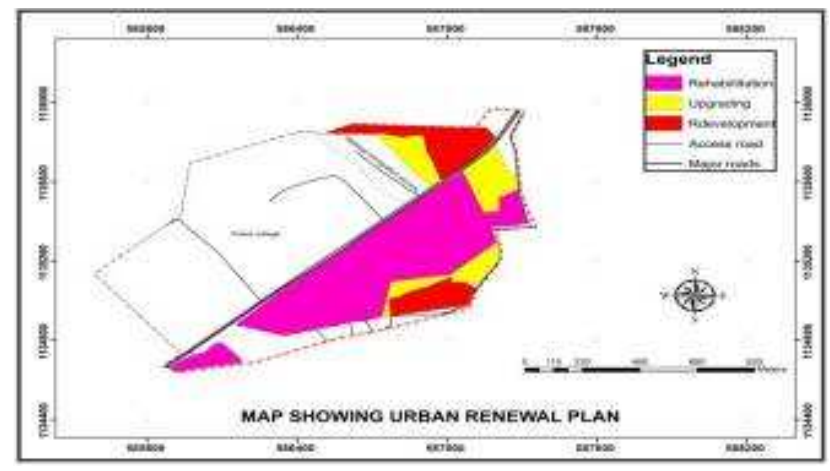

Figure 15: The proposed urban renewal plan 


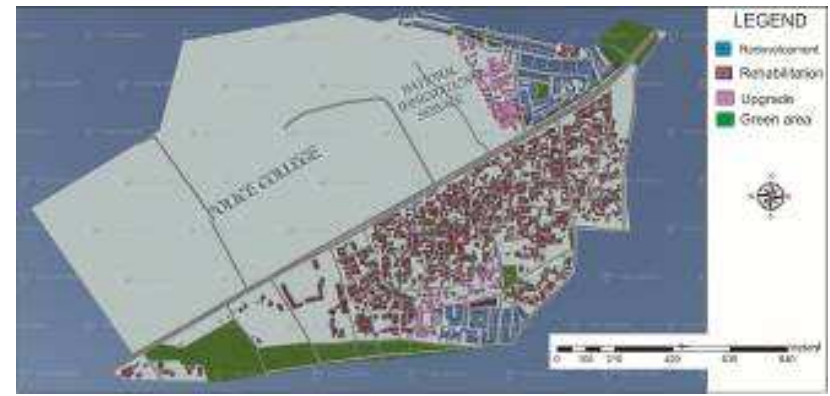

\section{PLAN IMPLEMENTATION}

This is the execution of a plan, design and model. The success of any plan lies on its implementation meaning that a plan only becomes a plan when it is translated physically on the ground. Thus, the various bodies responsible for implementation of the proposals made in this study area specified in the table below

Figure 16: Proposed urban renewal plan (3d design)

Table7. Table showing the plan implementation

\begin{tabular}{|l|l|}
\hline \multicolumn{1}{|c|}{ PROJECT } & \multicolumn{1}{c|}{ IMPLEMENTATION BODY } \\
\hline $\begin{array}{l}\text { Education and enlightenment of people of } \\
\text { Yelwan Tudu on issues of urban renewal }\end{array}$ & Bauchi state Ministry of information \\
\hline Relocation of people willing to relocate & Bauchi state urban planning and development board \\
\hline Land acquisition and compensation & Bauchi state urban planning and development board \\
\hline Reconstruction of access roads & Bauchi Ministry of works \\
\hline Provision of water supply & Bauchi state Water Board \\
\hline Enlightenment on Refuse collection & Bauchi state environmental agency \\
\hline Provision of commercial and recreational facilities & Bauchi state urban planning and development Board \\
\hline Completion of development & Bauchi state urban planning and development Board \\
\hline
\end{tabular}

PHASING OF PLAN IMPLEMENTATION

The plan implementation for the study area is a 10 years plan (2017-2027) grouped into two phases I (2017-2022) and II (2022-2027).

TABLE8. Table Showing the Phases of Plan Implementation

\begin{tabular}{|c|c|c|}
\hline PHASE & PROJECT & PERIOD \\
\hline ONE(I) 2017 & $\begin{array}{l}\text { Education and enlightenment of people of } \\
\text { Yelwan Tudu on urban renewal issues }\end{array}$ & 2017 \\
\hline 2 & Land acquisition and compensation & 2017- 2018 \\
\hline 8 & Construction of untarred access roads & 20192021 \\
\hline 8 & Provision of water source & 2022 \\
\hline TWO(II) 2022 & Enlightenment and provision of waste bins & 2022 \\
\hline & Provision of commercial and Recreational facilities & $2023 \quad 2025$ \\
\hline & Completion of development & 2025 \\
\hline
\end{tabular}

\section{SOURCES OF FUNDS FOR IMPLEMENTATION}

The success of every plan implementation depends on the financial source and commitment. For the purpose of this plan, the following sources are identified for the implementation of the project.

$>$ Federal Government of Nigeria (Special Intervention)

$>$ Bauchi state Government

$>$ Bauchi Local Government Council

$>$ Non-governmental Organization

$>$ World Bank Assisted Project

$>$ Private Sector Intervention

$>$ Community Based Organization

\section{CONCLUSION}

The analysis of various variables using the GIS platform has been demonstrated in this research paper to be an excellent response to the methodological shortcomings of conventional tools. Urban renewal studies usually generate large volumes of data which the manual methods of analysis cannot handle. The GIS technique explored in this study showed strengths in terms of analytical precision, accuracy of results, timeliness and display of results in the form of maps that the conventional methods cannot provide.

\section{REFERENCES}

[1] Egolum C. C., Emoh F. I., (2017). The issues and challenges of urban renewal in a developing economy. International journal of development and economic sustainability. 5 (1): 32-44

[2] Omole, F. K. (2000). Urban Renewal Process Issues and Strategies; Concept Books and Publication Company Nig. Limited, Lagos, Nigeria.

[3] Uloko, C. E. and J. E Agbonoga, (2005). An Essential Handbook for Physical Planners .Kaduna, Alex.

[4] Obateru O.I. (1968). Land Subdivision; Evans Brothers (Nig) Publishers. Ltd. 